\title{
LEAF AREA PREDICTION MODELS FOR Zinnia elegans JACQ., Zinnia haageana REGEL AND 'PROFUSION CHERRY'
}

\author{
Ana Christina Rossini Pinto ${ }^{1}$; Teresinha de Jesus Deléo Rodrigues ${ }^{1 *}$; José Carlos Barbosa²; \\ Izabel Cristina Leite ${ }^{1}$ \\ ${ }^{\prime}$ UNESP/FCAV - Depto. de Biologia Aplicada à Agropecuária, Via de Acesso Prof. Paulo Donato Castellane, s/n- \\ 14884-900 - Jaboticabal, SP - Brasil. \\ ${ }^{2}$ UNESP/FCAV - Depto. de Ciências Exatas. \\ *Corresponding author <tedelro@fcav.unesp.br >
}

\begin{abstract}
Leaf area measurements are of value in physiological and agronomic studies. The use of prediction models to estimate leaf area is a simple, accurate and nondestructive method. The present work suggests leaf area prediction models for Zinnia elegans ('Liliput' and 'Thumbelina'), Z. haageana ('Carpet Persa') and Z. elegans x Z. angustifolia ('Profusion Cherry'), potential flower potplant cultivars. At the stages of visible apical flower bud and flowering, 250 and 300 leaves were collected from greenhouse grown plants, respectively, at each season (fall, winter, spring and summer), totaling 1,000 and 1,200 leaves, for each developmental stage. The maximum length (L), maximum width (W) and real leaf area (RLA) were measured with a Digital Image Analysis System - Delta T Devices. The relation between RLA and the product of length by width $(\mathrm{LW})$, was studied through linear models, for each cultivar, at each developmental stage. The models for the flower bud stage were: RLA $=0.0009+0.7765 \mathrm{LW}$ ('Profusion Cherry'), RLA $=0.0021+0.8156$ LW ('Thumbelina'), RLA $=0.0031+0.8003$ LW ('Liliput'), RLA $=0.0036+0.7719 \mathrm{LW}$ ('Carpet Persa'), and for flowering stage: RLA = 0.0029 + 0.7899 LW ('Profusion Cherry'), $\quad$ RLA $=0.8318 \mathrm{LW} \quad$ ('Thumbelina'), $\quad$ RLA $=0.001+0.8417$ LW ('Liliput'), RLA $=0.0042+0.723 \mathrm{LW}$ ('Carpet Persa'). Models were considered adequate to estimate leaf area.
\end{abstract}

Key words: floriculture, potted plants, linear regression

\section{MODELOS PARA ESTIMATIVA DA ÁREA FOLIAR DE Zinnia elegans JACQ., Zinnia haggeana REGEL E 'PROFUSION CHERRY'}

\begin{abstract}
RESUMO: A determinação da área foliar é importante em estudos fisiológicos e agronômicos. O uso de modelos para estimativa da área foliar é um método simples, de boa precisão e não destrutivo. O presente trabalho determina modelos para estimativa da área foliar de Zinnia elegans ('Liliput' e 'Thumbelina'), $Z$. haageana ('Carpet Persa') e Z. elegans x Z. angustifolia ('Profusion Cherry'), cultivares ornamentais com potencial para produção em vaso. Foram coletadas 250 e 300 folhas, respectivamente, nos estádios de gema florífera apical visível e de floração, de plantas cultivadas em casa de vegetação, em cada estação (outono, inverno, primavera e verão), totalizando 1000 e 1200 folhas, para cada estádio de desenvolvimento. Determinaram-se o comprimento (C) e a largura (L) máximas e a área foliar real (AFR), com auxílio de um sistema de análise de imagem digital - Delta T Devices. Estudaram-se as relações existentes entre a AFR e o produto do comprimento pela largura da folha $(\mathrm{CL})$, por modelos de regressão linear, para cada cultivar, em cada estádio de desenvolvimento. Os modelos, para o estádio de gema florífera, AFR = 0,0009 + 0,7765 CL ('Profusion Cherry'), AFR = 0,0021 + 0,8156 CL ('Thumbelina'), AFR =0,0031 + 0,8003 CL ('Liliput'), AFR = 0,0036 + 0,7719 CL ('Carpet Persa'), e para o estádio de floração, AFR =0,0029 + 0,7899 CL ('Profusion Cherry'), AFR =0,8318 CL ('Thumbelina'), AFR =0,001 + 0,8417 CL ('Liliput'), $\mathrm{AFR}=0,0042+0,723 \mathrm{CL}$ ('Carpet Persa'), são adequados para estimar a área foliar real.
\end{abstract}

Palavras-chave: floricultura, plantas envasadas, regressão linear

\section{INTRODUCTION}

Leaf area measurements are of value in physiological and agronomic studies (Miller et al., 1956; McKee, 1964; Pereira \& Machado, 1987; Van Volkenburgh, 1994). Among the various methods to measure leaf area (Evans, 1972, Causton \& Venus, 1981, Norman \& Campbell, 1991), the nondestructive methods allow the replication of measurements during the growth period, reducing some of the experimental variability associated to destructive sampling procedures (NeSmith, 1992). They are very useful in studies of plant activity, which require a nondestructive method of measuring leaf area (Wendt, 1967) and also when the number of available plants is limited. 
The use of regression equations to estimate leaf area is a nondestructive, simple, quick, accurate, reliable and not expensive method. The usual procedure of this method involves measuring lengths, widths, and areas of a sample of leaves and then calculating the several possible regression coefficients, or leaf factors, to estimate areas of subsequent samples (Wiersma \& Bailey, 1975). Accurate and simple mathematical models eliminate the need for leaf area meters or time-consuming, geometric reconstructions (Gamiely et al., 1991).

Several prediction models have been determined to estimate leaf area for numerous crops, but little information is available for Zinnia elegans Jacq. (Barbosa et al., 1996) and none for Zinnia haageana and zinnia interspecific hybrids. Leaves are formed in a characteristic pattern for each species, demanding specific leaf shape (Sinha, 1999). Therefore, prediction models must be determined for each species, and for cultivars of a given species which presents different leaf shape.

Zinnias are popular garden flowers, cultivated worldwide (Stimart et al., 1987, Linderman \& Ewart,1990). Their ornamental value as cut flowers is well-known (Boyle \& Stimart, 1983) and, currently they are also used in containers, patio pots and windowboxes in countries of Northern hemisphere.

More recently, potted zinnias appeared in the São Paulo State flower market, and some new cultivars are making zinnia a promise as a flowering pot plant. 'Profusion Cherry' is a dwarf, compact interspecific hybrid plant for garden, patio and pot (Sakata, 2001). In Brazil, 'Profusion Cherry' could represent an important new hybrid for the potplant flower market. Zinnia haageana 'Persian Carpet', Z. elegans 'Thumbelina' and 'Liliput' are dwarfs and low growing garden plants (Metcalf \& Sharma, 1971). The objective of this study was developing regression models that would accurately predict leaf areas, a helpful tool for future physiological and agronomic studies of these zinnia cultivars.

\section{MATERIAL AND METHODS}

Leaves were collected from plants grown in a polyethylene-covered greenhouse, in Jaboticabal ( $21^{\circ} 15^{\prime} 22^{\prime \prime} \mathrm{S}, 48^{\circ} 15^{\prime} 18^{\prime \prime} \mathrm{W}$; mean altitude $\left.610 \mathrm{~m}\right)$, SP, Brazil. Local climate is Cwa, after Köppen's classification, subtropical humid type (Volpe et al., 1989).

Zinnia haageana Regel 'Carpet Persa', Z. elegans Jacq. 'Thumbelina' and 'Liliput', and 'Profusion Cherry' (interspecific hybrid of Z. elegans and Z. angustifolia HBK) were sown in polystyrene plug trays (model CM 128-62) containing commercial media and transplanted to pots when the second nodal leaves were fully expanded. Plants were kept under natural photoperiod, at minimum, maximum and mean temperatures of $6.0,37.5$ and $23.8 \pm 1{ }^{\circ} \mathrm{C}$ in the fall; $2.5,38.0$ and $21.4 \pm 1^{\circ} \mathrm{C}$ in the winter; 17.8, 43.0 and $28.2 \pm 1{ }^{\circ} \mathrm{C}$ in the spring; and $19.0,40.0$ and $28.4 \pm 1{ }^{\circ} \mathrm{C}$ in the summer. Daily relative humidities varied from 28 to $99 \%$ in the fall; 26 to 95 $\%$ in the winter; 33 to $96 \%$ in the spring; and 40 to 99 $\%$ in the summer. Weekly evaluations carried with a steady state porometer (Li-Cor, Model LI-1600) during the production cycle pointed mean maximum photosynthetic photon flux inside the greenhouse equal to $565.1 \mu \mathrm{mol} \mathrm{m} \mathrm{s}^{-2}$ in the fall; $499.4 \mu \mathrm{mol} \mathrm{m} \mathrm{m}^{-2} \mathrm{~s}^{-1}$ in the winter; $898.6 \mu \mathrm{mol} \mathrm{m} \mathrm{m}^{-2} \mathrm{~s}^{-1}$ in the spring; and $870.4 \mu \mathrm{mol} \mathrm{m}^{-2} \mathrm{~s}^{-1}$ in the summer.

At each season (fall, winter, spring and summer), potted plants were arranged in sixteen treatments (combination of two pot sizes, two growing systems and four cultivars), in a completely randomized design $(n=4)$. Growing systems (free sprout of all plant buds or removing apical flower bud to estimulate side branch growth) were applied when apical flower bud presented between 3-5 $\mathrm{mm}$ in length. Plants were developed, respectively, in two plastic pots, 0.60 and $1.3 \mathrm{~L}$, with one plant per pot, filled with commercial growing media and fertilized with Osmocote Sierra ${ }^{\text {Scotts }} 15-10-10+$ micro, $1.08 \mathrm{~g}$ per $0.6 \mathrm{~L}$ pot and $1.98 \mathrm{~g}$ per $1.3 \mathrm{~L}$ pot.

Linear regression models were developed to predict leaf area for the apical flower bud (3-5 $\mathrm{mm}$ in length) and flowering (inflorescence with ray florets completely open) stages; 250 and 300 leaves, were collected at random, respectively, from the apical flower bud and flowering stages, at each season, totaling 1,000 and 1,200 leaves per each developmental stage, for each zinnia species. Sampled leaves represented the full spectrum of measurable leaf sizes presented at the developmental stage, and did not present any damage and deformation caused by diseases, insects or other external factors.

Leaf length $(\mathrm{L} ; \mathrm{cm})$ was measured along the lamina midrib, from the point of lamina attachment to the tip, and leaf width $(\mathrm{W} ; \mathrm{cm})$ was measured perpendicularly to lamina midrib, from tip to tip at the widest part of the lamina. The real leaf area (RLA) was determined for each lamina with a Digital Image Analysis System Delta T Devices, calibrated to $1.0 \mathrm{~mm}^{2}$.

Data were fitted to linear regressions to establish the best fitted regression model, which represents the relationship between RLA and the product of L by W. The model was $Y=a+b X$, and without intercept $Y=b X$, adjusted by the least square method. RLA was taken as the dependent variable ( $\mathrm{Y})$ and the product of $\mathrm{L}$ by $\mathrm{W}$ as the independent variable (X). Statistical criteria for model selection were $\mathrm{F}$ test, mean square error and coefficient of determination. To test the hypothesis $\mathrm{H}_{0}: \mathrm{a}=0$, where the model regression line passes through the origin, $\mathrm{F}$ test was applied, obtained by the difference between the residual sum of squares of the reduced model $(\mathrm{Y}=\mathrm{bX})$ and the full model $(Y=a+b X)$, according to Seber (1977). To verify if a single regression model could be used for all culti- 
vars, at each developmental stage, the F test was applied, obtained by the difference between the residual sum of squares of the model that considered the different coefficients for each cultivar against the model which cultivar effects were not considered (Seber, 1977).

\section{RESULTS AND DISCUSSION}

No differences between leaf shape of plants from different growing systems or pot size were observed, at all developmental stages, for 'Profusion Cherry', Zinnia elegans 'Thumbelina' and 'Liliput' and Zinnia haageana 'Carpet Persa'. Evaluations of the coefficients of determination $\left(\mathrm{R}^{2}\right)$, F ratio for model adjustment (Ftest ${ }_{\text {model }}$ ), and mean square error (MSE) of analysis of variance to test models, for each calculated regression, indicated that the obtained models accurately predict leaf areas for 'Profusion Cherry', 'Thumbelina', 'Liliput' and 'Carpet Persa', at the studied developmental stages (Tables 1, 2, 3 e 4). All coefficients of determination were greater than 0.95 , the $\mathrm{F}$ test for models adjust were significant $P=0.01$, and the mean square errors were lower.

In practice, because of model simplicity, high coefficient of determination values, and mean square errors very close to the linear model $(\mathrm{Y}=\mathrm{a}+\mathrm{bX})$, it is recom- mended, for 'Thumbelina', at the flowering stage, adoption of the model RLA $=0.8318 \mathrm{LW}$, in detriment to model RLA $=0.0008+0.8270$ LW (Table 2). Since the $\mathrm{F}$ test for the null hypothesis $\left(\mathrm{H}_{0}: \mathrm{a}=0\right)$ compared against the alternative hypothesis $\left(\mathrm{H}_{\mathrm{a}}: \mathrm{a} \neq 0\right)$ for the model $\mathrm{Y}=\mathrm{a}$ $+\mathrm{bX}$ was not significant, the intercept does not differ from zero, what justifies the adoption of the linear model without intercept $(\mathrm{Y}=\mathrm{bX})$.

However, for 'Profusion Cherry', 'Liliput' and 'Carpet Persa', for both developmental stages, and for 'Thumbelina' at apical flower bud stages, the linear models $(\mathrm{Y}=\mathrm{a}+\mathrm{bX})$ are recomended. The $\mathrm{F}$ test for the hypothesis $\mathrm{H}_{0}: \mathrm{a}=0$ against the alternative hypothesis $\mathrm{H}_{\mathrm{a}}$ : $a \neq 0$, for the models $\mathrm{Y}=\mathrm{a}+\mathrm{bX}$, was significant, confirming the hypothesis that intercept differ from zero (Tables 1, 2, 3 e 4).

Therefore, models RLA $=0.0009+0.7765 \mathrm{LW}$ ('Profusion Cherry'), RLA $=0.0021+0.8156 \mathrm{LW}$ ('Thumbelina'), RLA $=0.0031+0.8003$ LW ('Liliput'), RLA $=0.0036+0.7719 \mathrm{LW}$ ('Carpet Persa') and, for flowering stage, RLA $=0.0029+0.7899 \mathrm{LW}$ ('Profusion Cherry'), $\quad$ RLA $=0.8318$ LW ('Thumbelina'), $\mathrm{RLA}=0.001+0.8417$ LW ('Liliput'), RLA $=0.0042+$ 0.723 LW ('Carpet Persa') are recommended to estimate leaf area (Tables 1, 2, 3 and 4). The F tests obtained by

Table 1 - Linear regression analysis between real leaf area (Y) and the product of length by width (X) for 'Profusion Cherry' leaves,for the visible apical flower bud and flowering stages.

\begin{tabular}{|c|c|c|c|c|}
\hline \multirow{3}{*}{ Statistics } & \multicolumn{4}{|c|}{ Length Width Product $(\mathrm{X})$} \\
\hline & \multicolumn{2}{|c|}{ Apical flower bud stage } & \multicolumn{2}{|c|}{ Flowering stage } \\
\hline & $Y=a+b X$ & $\mathrm{Y}=\mathrm{bX}$ & $Y=a+b X$ & $\mathrm{Y}=\mathrm{bX}$ \\
\hline $\mathrm{a}$ & 0.0009 & - & 0.0029 & - \\
\hline $\mathrm{b}$ & 0.7765 & 0.7841 & 0.7899 & 0.8145 \\
\hline F test & $85998.3 * *$ & $266111.0 * *$ & $69694.5 * *$ & $471784.0 * *$ \\
\hline$F$ test $_{(\mathrm{Ho}: \mathrm{a}=0)}$ & $11.99 * *$ & - & $79.69 * *$ & - \\
\hline MSE & 0.0000197031 & 0.0000199198 & 0.0000182850 & 0.0000194851 \\
\hline $\mathrm{R}^{2}$ & 0.9885 & 0.9963 & 0.9831 & 0.9975 \\
\hline
\end{tabular}

Table 2 - Linear regression analysis between real leaf area $(\mathrm{Y})$ and the product of length by width $(\mathrm{X})$ for Zinnia elegans 'Thumbelina' leaves, for the visible apical flower bud and flowering stages.

\begin{tabular}{|c|c|c|c|c|}
\hline \multirow{3}{*}{ Statistics } & \multicolumn{4}{|c|}{ Length Width Product (X) } \\
\hline & \multicolumn{2}{|c|}{ Apical flower bud stage } & \multicolumn{2}{|c|}{ Flowering stage } \\
\hline & $\mathrm{Y}=\mathrm{a}+\mathrm{bX}$ & $\mathrm{Y}=\mathrm{bX}$ & $\mathrm{Y}=\mathrm{a}+\mathrm{bX}$ & $\mathrm{Y}=\mathrm{bX}$ \\
\hline a & 0.0021 & - & 0.0008 & - \\
\hline $\mathrm{b}$ & 0.8156 & 0.8304 & 0.8270 & 0.8318 \\
\hline F test ${ }_{\text {(model) }}$ & $132904.0 * *$ & $401118.0 * *$ & $58425.4 * *$ & $282432.0 * *$ \\
\hline$F$ test ${ }_{(\mathrm{Ho}: \mathrm{a}=0)}$ & $64.63 * *$ & - & $2.44^{\mathrm{ns}}$ & - \\
\hline MSE & 0.0000219041 & 0.0000232992 & 0.0000615414 & 0.0000616152 \\
\hline $\mathrm{R}^{2}$ & 0.9925 & 0.9975 & 0.9799 & 0.9957 \\
\hline
\end{tabular}

${ }^{\mathrm{n}}$ nonsignificant at $P>0.05 ;{ }^{* *}$ - significant at $P<0.01$; a and $\mathrm{b}$ - regression parameters estimation; $\mathrm{F}$ test ${ }_{\text {(model) }}-\mathrm{F}$ test for models adjust; F test $_{(\text {Ho: }:=0)}-\mathrm{F}$ test for Ho: a $=0$ versus Ha: $\mathrm{a} \neq 0$; MSE - Mean Square Error of ANOVA to model test; $\mathrm{R}^{2}-$ coefficient of determination. 
Table 3 - Linear regression analysis between real leaf area $(\mathrm{Y})$ and the product of length by width $(\mathrm{X})$ for Zinnia elegans 'Liliput' leaves, for the visible apical flower bud and flowering stages.

\begin{tabular}{|c|c|c|c|c|}
\hline \multirow{3}{*}{ Statistics } & \multicolumn{4}{|c|}{ Length Width Product (X) } \\
\hline & \multicolumn{2}{|c|}{ Apical flower bud stage } & \multicolumn{2}{|c|}{ Flowering stage } \\
\hline & $Y=a+b X$ & $\mathrm{Y}=\mathrm{bX}$ & $Y=a+b X$ & $\mathrm{Y}=\mathrm{bX}$ \\
\hline $\mathrm{a}$ & 0.0031 & - & 0.0010 & - \\
\hline $\mathrm{b}$ & 0.8003 & 0.8135 & 0.8417 & 0.8471 \\
\hline $\mathrm{F}$ test (model) & $147004.0 * *$ & $431901.0 * *$ & $173947.0 * *$ & $707613.0 * *$ \\
\hline$F$ test ${ }_{(\mathrm{Ho}: \mathrm{a}=0)}$ & $59.69 * *$ & - & $9.59 * *$ & - \\
\hline MSE & 0.0000523179 & 0.0000553917 & 0.0000298662 & 0.0000300802 \\
\hline $\mathrm{R}^{2}$ & 0.9933 & 0.9977 & 0.9932 & 0.9983 \\
\hline
\end{tabular}

Table 4 - Linear regression analysis between real leaf area $(\mathrm{Y})$ and the product of length by width $(\mathrm{X})$ for Zinnia haageana 'Carpet Persa' leaves, for the visible apical flower bud and flowering stages.

\begin{tabular}{|c|c|c|c|c|}
\hline \multirow{3}{*}{ Statistics } & \multicolumn{4}{|c|}{ Length Width Product (X) } \\
\hline & \multicolumn{2}{|c|}{ Apical flower bud stage } & \multicolumn{2}{|c|}{ Flowering stage } \\
\hline & $\mathrm{Y}=\mathrm{a}+\mathrm{bX}$ & $\mathrm{Y}=\mathrm{bX}$ & $Y=a+b X$ & $Y=b X$ \\
\hline a & 0.0036 & - & 0.0042 & - \\
\hline $\mathrm{b}$ & 0.7719 & 0.7933 & 0.7230 & 0.7568 \\
\hline F test & $70279.0 * *$ & $216177.0 * *$ & $31922.4 * *$ & $198902.0 * *$ \\
\hline$F$ test & $79.33 * *$ & - & $83.33 * *$ & - \\
\hline MSE & 0.0000531089 & 0.0000572731 & 0.0000414052 & 0.0000442482 \\
\hline $\mathrm{R}^{2}$ & 0.9860 & 0.9954 & 0.9638 & 0.9940 \\
\hline
\end{tabular}

**significant at $P<0.01$; a and $\mathrm{b}$ - regression parameters estimation; $\mathrm{F}$ test ${ }_{\text {(model) }}-\mathrm{F}$ test for models adjust; $\mathrm{F}$ test ${ }_{(\mathrm{Ho}: \mathrm{a}=0)}-\mathrm{F}$ test for Ho: $\mathrm{a}=0$ versus Ha: $\mathrm{a} \neq 0$; MSE - Mean Square Error of ANOVA to model test; $\mathrm{R}^{2}$ - coefficient of determination.

the difference between the residual sum of squares of the model that considered the different coefficients for each cultivar against the model which cultivars effect was not considered were significant for the apical flower bud $\left(\mathrm{F}=98.17^{* *}, P<0.01\right)$ and flowering $\left(\mathrm{F}=405.02^{* *}, P<0.01\right)$ stages, indicating that it is not possible to use a single regression model for all studied cultivars.

Coefficients of determination $\left(\mathrm{R}^{2}\right)$ indicate that RLA estimated by the chosen models are close to the areas determined by the area meter (Figures 1 to 8 ). Therefore, $98.85 \%$ and $98.31 \%$ of the variability observed for RLA (Table 1) could be explained by the variability of the product $\mathrm{L} \times \mathrm{W}$ for the 'Profusion Cherry' leaf, for the models $\mathrm{RLA}=0.0009+0.7765 \mathrm{LW}$ (apical flower bud stage) and RLA $=0.0029+0.7899 \mathrm{LW}$ (flowering stage). Tables 2 and 3 show that $99.25 \%$ and $97.99 \%$, and $99.33 \%$ and $99.32 \%$ of the variability observed for leaf area could be explained by the variation of the product L x W for 'Thumbelina' and 'Liliput' leaves, respectively, for the models RLA $=0.0021+0.8156 \mathrm{LW}$ (apical flower bud stage) and RLA $=0.8318 \mathrm{LW}$ (flowering stage), and RLA $=0.0031+0.8003 \mathrm{LW}$ (apical flower bud) and RLA $=0.001+0.8417 \mathrm{LW}$ (flowering stage). Table 4 shows that $98.60 \%$ and $96.38 \%$ of the variability observed for leaf area could be explained by the product of L x W for the 'Carpet Persa' leaf, for models
RLA $=0.0036+0.7719$ LW (apical flower bud stage) and $\mathrm{RLA}=0.0042+0.7230 \mathrm{LW}$ (flowering stage). It is not necessary to establish other more complex regression models in practice.

Defined models could be used to estimate RLA, at the apical flower bud and flowering stages, for the sampled range of L and W for 'Profusion Cherry', 'Thumbelina', 'Liliput' and 'Carpet Persa' leaves, as shown in Table 5. The studied range, probably, is representative for $Z$. elegans and Z. haageana species, because it includes $\mathrm{L}$ and $\mathrm{W}$ values mentioned in the literature, for the botanic description of these species (Torres, 1963). In addition, leaves were sampled during the four seasons of the year, covering distinctive environmental conditions, allowing wide variations in leaf shape. According to Cutter (1987), ligth, temperature and photoperiod affect foliar primordium development, altering leaf shape.

Models based on one single measurement offer the advantages of more efficient data collection, less complex calculations (NeSmith, 1992), and require less time for leaf measurement (Robbins \& Pharr, 1987). Nonetheless they were less satisfactory for predicting RLA of 'Liliput', 'Thumbelina', 'Carpet Persa' and 'Profusion Cherry' (data not shown). These models had coefficients of determination inferior to those obtained when using the product of length by width (LW). 
Table 5 - Sampled range of leaf length, width and the product of length by width for 'Profusion Cherry', Zinnia elegans 'Thumbelina' and 'Liliput' and Zinnia haageana 'Carpet Persa' leaf, for the visible apical flower bud and flowering stages.

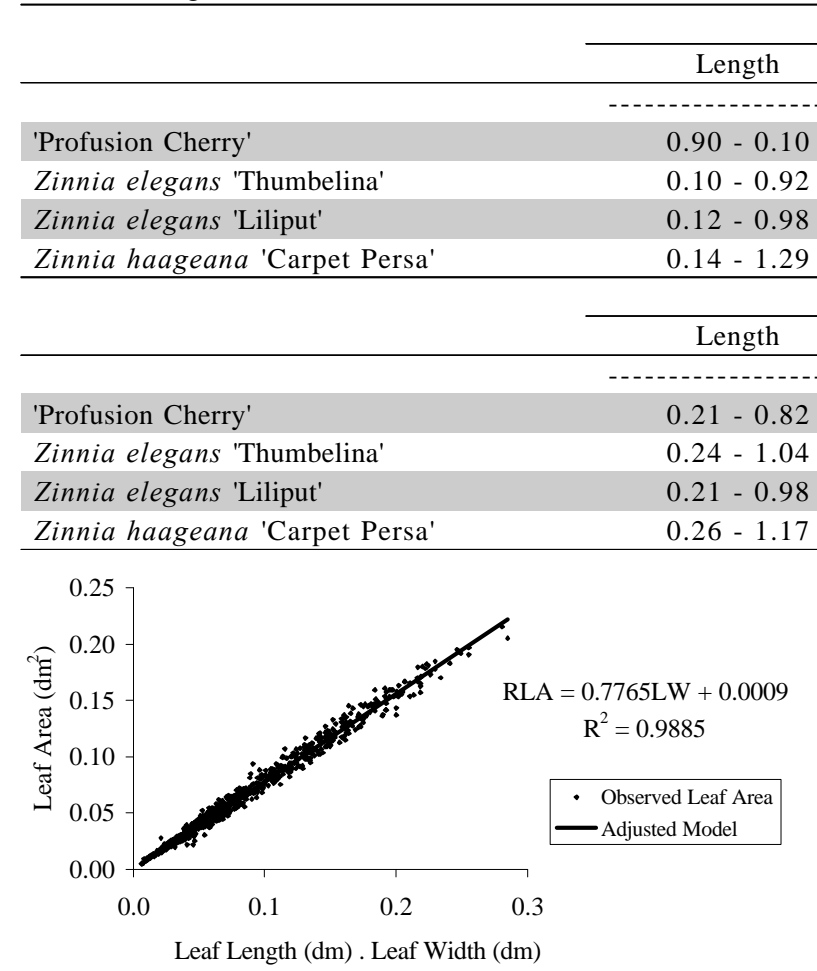

Figure 1 - Relation between real leaf area (RLA) and the product of length by width (LW) for 'Profusion Cherry' leaves, at the visible apical flower bud stage.

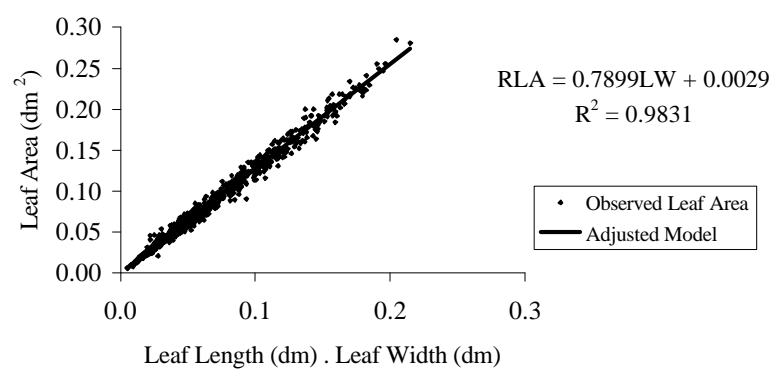

Figure 2 - Relation between real leaf area (RLA) and the product of length by width (LW) for 'Profusion Cherry' leaves, at the flowering stage.

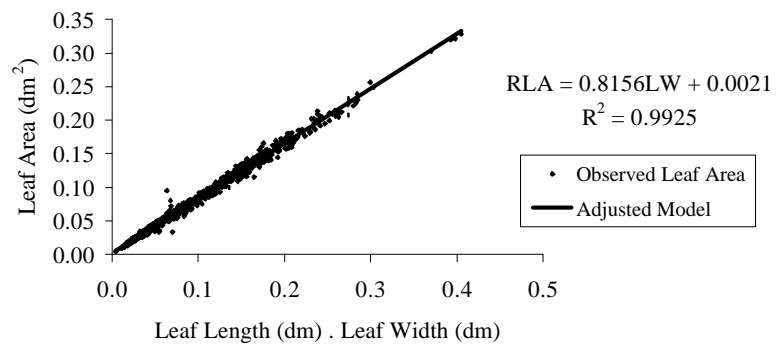

Figure 3 - Relation between real leaf area (RLA) and the product of length by width (LW) for Zinnia elegans 'Thumbelina' leaves, at the visible apical flower bud stage.
Apical flower bud stage

Width Length-Width Product

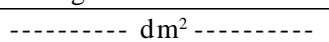

$0.0066-0.2848$

$0.0104-0.4050$

$0.0112-0.5782$

$0.0084-0.3741$

$\begin{array}{ll}0.07-0.59 & 0.0112-0.5782 \\ 0.04-0.34 & 0.0084-0.3741\end{array}$

Flowering stage

\begin{tabular}{cc} 
Width & Length-Width Product \\
\hline $0.08-0.34$ & $0.0176-0.2449$ \\
$0.12-0.54$ & $0.0324-0.5616$ \\
$0.11-0.58$ & $0.0231-0.4840$ \\
$0.07-0.33$ & $0.0192-0.3234$
\end{tabular}

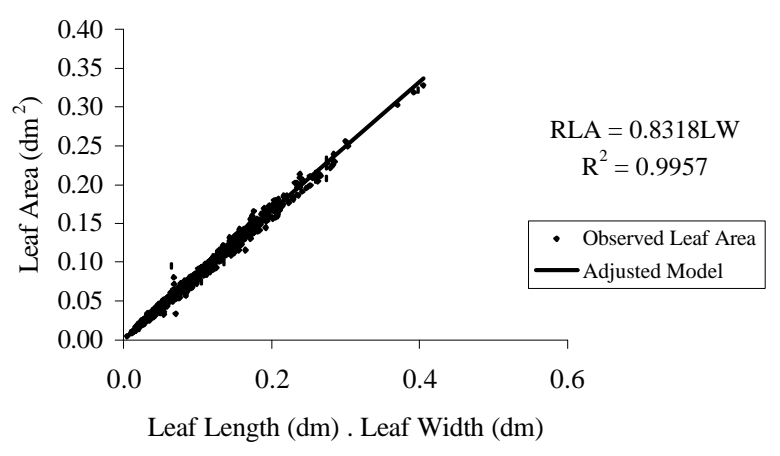

Figure 4 - Relation between real leaf area (RLA) and the product of length by width (LW) for Zinnia elegans 'Thumbelina' leaves, at the flowering stage.

The models for 'Thumbelina', RLA = $0.0021+0.8156 \mathrm{LW}$ (flower bud stage) and RLA $=0.8318 \mathrm{LW}$ (flowering stage), and for 'Liliput', RLA $=0.0031+0.8003 \mathrm{LW}$ (flower bud stage) and RLA $=0.001+0.8417$ LW (flowering stage), presented very similar slope (b) to the ones obtained by Barbosa et al. (1996) for Z. elegans 'Double Choice Mixed', a cut flower cultivar, which presents models $\mathrm{A}=0.811541 \mathrm{LW}$ for flower bud stage and $\mathrm{A}=0.801052 \mathrm{LW}$ for flowering stage. These studied Zinnia elegans cultivars have a very similar leaf shape. The percentage of the product of $\mathrm{L} \times \mathrm{W}$ to estimate RLA, given by the coefficient $b$, are close. The coefficient $b$ obtained for Z. haageana and 'Profusion Cherry' (Tables 1 and 4) is lower and not similar to that of Z. elegans (Tables 2 and 3) since their leaf shapes are different. Z. haageana presents lanceolate leaves while $Z$. elegans oval or oblong leaves (Torres, 1963), and 'Profusion Cherry' have lance-shaped leaves, but not as lanceolated as $Z$. haageana. 


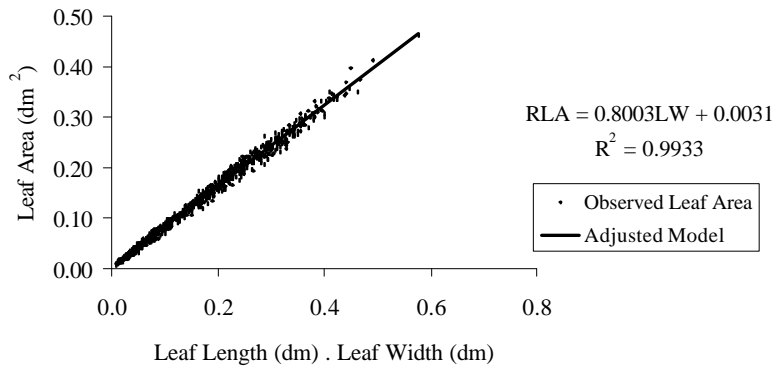

Figure 5 - Relation between real leaf area (RLA) and the product of length by width (LW) for Zinnia elegans 'Liliput' leaves, at the visible apical flower bud stage.

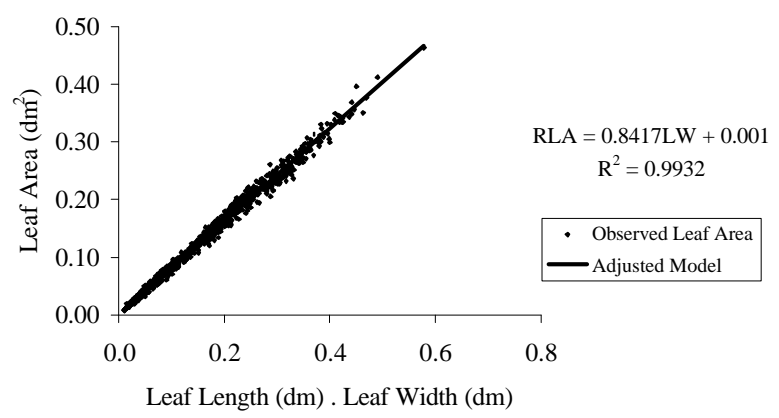

Figure 6 - Relation between real leaf area (RLA) and the product of length by width (LW) for Zinnia elegans 'Liliput' leaves, at the flowering stage.

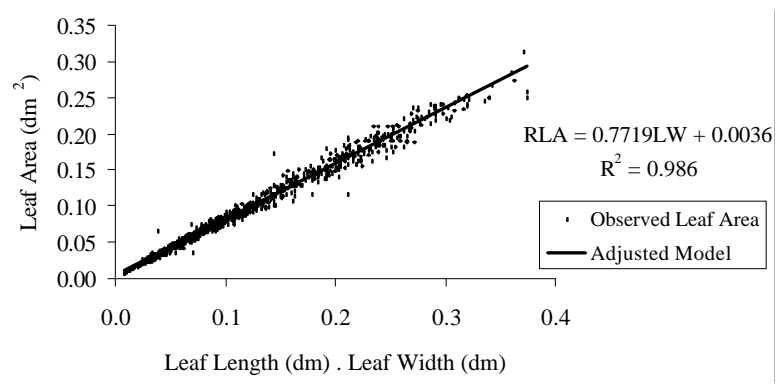

Figure 7 - Relation between real leaf area (RLA) and the product of length by width (LW) for Zinnia haageana 'Carpet Persa' leaves, at the visible apical flower bud stage.

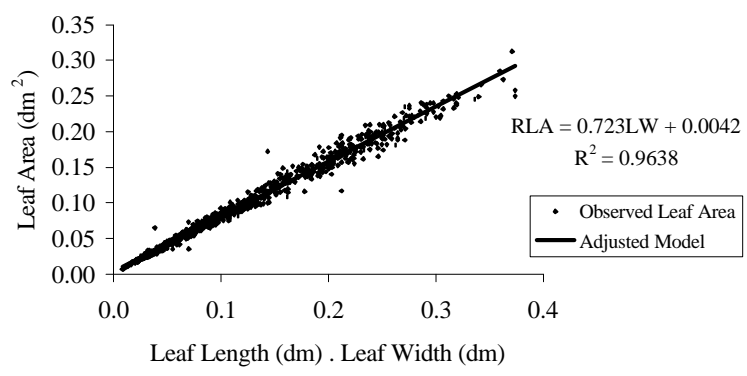

Figure 8 - Relation between real leaf area (RLA) and the product of length by width (LW) for Zinnia haageana 'Carpet Persa' leaves, at the flowering stage.

\section{ACKNOWLEDGMENTS}

To CNPq for research grant of first, second and third authors.

\section{REFERENCES}

BARBOSA, J.C.; PINTO, A.C.R.; GRAZIANO, T.T. Equações de regressão para estimativa da área foliar de Zinnia elegans Jacq. Científica, v.24, p.319-327, 1996.

BOYLE, T.H.; STIMART, D.P. Developmental responses of Zinnia to photoperiod. Journal of the American Society for Horticultural Science, v.108, p.1053-1059, 1983.

CAUSTON, D.R.; VENUS, J.C. The biometry of plant growth. London: Edward Arnold, 1981. 301p.

CUTTER, E.G. Anatomia vegetal. Parte II - Orgãos. São Paulo: Roca, 1987. 336p.

EVANS, G.C. The quantitative analysis of plant growth. Oxford: Blackwell, 1972. 734p.

GAMIELY, S.; RANDLE, W.M.; MILLS, H.A.; SMITTLE, D.A. A rapid and nondestructive method for estimating leaf area of onions. HortScience, v.26, p.206, 1991.

LINDERMAN, S.D.; EWART, L.C. Interspecific hybridization in zinnia: morphology, cytology, pollen examination, and powdery mildew resistance. Acta Horticulturae, n. 272, p.41-45, 1990.

McKEE, G.W. A coefficient for computing leaf area in hybrid corn. Agronomy Journal, v.56, p.240-242, 1964.

METCALF, H.N.; SHARMA, J.N. Germ plasm resources of the genus Zinnia L. Economic Botany, v.25, p.169-181, 1971.

MILLER, E.E.; SHADBOLT, C.A.; HOLM, L. Use of an optical planimeter for measuring leaf area. Plant Physiology, v.31, p.484-486, 1956.

NeSMITH, D.S. Estimating summer squash leaf area nondestructively. HortScience, v.27, p.77, 1992.

NORMAN, J.M.; CAMPBELL, G.S. Canopy structure. In: PEARCY, R.W.; EHLERINGER, J.R.; MOONEY, H.A.; RUNDEL, P.W. (Ed.). Plant physiological ecology: field methods and instrumentation. London: Chapman \& Hall, 1991. p.301-325.

PEREIRA, A.R.; MACHADO, E.C. Análise quantitativa do crescimento de comunidades vegetais. Campinas: IAC, 1987.33p. (Boletim Técnico, 114).

ROBBINS, N.S.; PHARR, D.M. Leaf area prediction models for cucumber from linear measurements. HortScience, v.22, p.1264-1266, 1987.

SAKATA'S RELIABLE SEEDS. Flower seed catalogue. California: Sakata Seed America, 2001. p.58.

SEBER, G.A.F. Linear regression analysis. New York: Jonh Wiley \& Sons, 1977. 465p.

SINHA, N. Leaf development in Angiosperms. Annual Review of Plant Physiology and Plant Molecular Biology, v.50, p.419-446, 1999.

STIMART, D.P.; BOYLE, T.H.; TERRY-LEWANDOWSKI, V.M. Genetic and physiological studies of Zinnia elegans, Z. angustifolia and their interspecific hybrids. HortScience, v.22, p.689-691, 1987.

TORRES, A.M. Taxonomy of Zinnia. Brittonia, v.15, p.1-25, 1963.

VAN VOLKENBURGH, E. Leaf and shoot growth. In: BOOTE, K.J.; BENNETT, J.M.; SINCLAIR, T.R.; PAULSEN, G.M. (Ed.) Physiology and determination of crop yield. Madison: ASA, 1994. p.101-120.

VOLPE, C.A.; BARBOSA, J.C.; MINCHIO, C.A.; ANDRÉ, R.G. Análise da precipitação mensal em Jaboticabal-SP. Ciência Agronômica, v.4, p.3-5, 1989.

WENDT, C.W. Use of a relationship between leaf length and leaf area to estimate the leaf area of cotton (Gossypium hirsutum L.), castors (Ricinus communis L.), and sorghum (Sorghum vulgare L.). Agronomy Journal, v.59, p.484-486, 1967

WIERSMA, J.V.; BAILEY, T.B. Estimation of leaflet, trifoliate, and total leaf areas of soybeans. Agronomy Journal, v.67, p.26-30, 1975.

$\overline{\text { Received October }} 22,2002$

Accepted July 21, 2003 